Western Washington University

Western CEDAR

\title{
Correlates of Average Daily Metabolism of Field- Active Zebra-Tailed Lizards (Callisaurus Draconoides)
}

William Karasov

Roger A. Anderson

Western Washington University, roger.anderson@wwu.edu

Follow this and additional works at: https://cedar.wwu.edu/biology_facpubs

Part of the Biology Commons

\section{Recommended Citation}

Karasov, William and Anderson, Roger A., "Correlates of Average Daily Metabolism of Field-Active Zebra-Tailed Lizards (Callisaurus Draconoides)" (1998). Biology Faculty and Staff Publications. 2.

https://cedar.wwu.edu/biology_facpubs/2 


\section{Correlates of Average Daily Metabolism of Field-Active Zebra-Tailed Lizards (Callisaurus draconoides)}

\author{
William H. Karasov ${ }^{1}$ \\ Roger A. Anderson ${ }^{2}$ \\ ${ }^{1}$ Department of Wildlife Ecology, University of Wisconsin, \\ Madison, Wisconsin 53706; ${ }^{2}$ Department of Biology, \\ Western Washington University, Bellingham, Washington \\ 98225-9160
}

Accepted by C.P.M. 8/11/97

\begin{abstract}
The extent of variation in reptile field metabolism, and its causal bases, are poorly understood. We studied the energetics of the insectivorous lizard Callisaurus draconoides at a site in the California Desert (Desert Center) and at a site at the southern tip of the Baja Peninsula (Cabo San Lucas; hereafter, Cabo). Reproducing Callisaurus were smaller at Cabo than at Desert Center. The allometry of metabolism with body mass can account for most differences in whole-animal metabolism. There was no significant effect of sex or source population on mass-adjusted metabolic rate in the laboratory (resting metabolism, measured by closedsystem respirometry) or in the field (field metabolism, measured with doubly labeled water). The mass-adjusted resting metabolism and field metabolism of gravid females and the field metabolism of juvenile lizards were not significantly different from those of nonreproductive adults. Temperature had a significant effect on resting metabolism $\left(\mathrm{Q}_{10}=2.7\right)$; fed lizards had resting metabolism that was $22 \%$ higher than that of fasted lizards; field metabolism was positively correlated with growth rate in juveniles; and field metabolism of adults increased from spring to late summer at Desert Center by $25 \%$, probably because of longer activity period length and slightly higher activity period body temperature. We calculated from water influx and field metabolism that juveniles allocated $18 \%$ of their metabolizable energy intake to growth and that most energy deposited into eggs was transferred from energy stores rather than ingested in the weeks prior to laying.
\end{abstract}

\section{Introduction}

It is axiomatic that measures of resting metabolic rate (RMR; Bennett and Dawson 1976; Andrews and Pough 1985) and

Physiological Zoology 71(1):93-105. 1998. (C) 1998 by The University of Chicago. All rights reserved. 0031-935X/98/7101-9668\$03.00 field metabolic rate (FMR; Nagy 1982) have a direct correlation with body size. Relatively few studies, however, have focused on residual variation in RMR related to differences in season (Tsuji 1988) or population (Heusner and Jameson 1981; Tsuji 1988; Beaupre et al. 1993), and few studies have examined habitat-related differences in field energetics among lizard populations (Karasov and Anderson 1984; Brown et al. 1992; Brown and Perez-Mellado 1994). The study of variability over time within populations and between populations can provide insights into the range of phenotypic variation within individuals versus genotypic variation among individuals. Studies of variability help place bounds on rates of energy flow within individuals and the rates of allocation of energy to maintenance, growth, and reproduction. These rates of energy flow in individuals collectively determine rates of production in populations. Moreover, comparisons between sample sites and times focus attention on factors that cause variation in FMR, including changes in thermoregulation (Adolph and Porter 1993), amount of daily activity (Karasov and Anderson 1984), and intensity of daily activity (Brown and Perez-Mellado 1994). The ability to predict FMR accurately requires extensive knowledge of the factors that compose and influence the rates of energy flow through individuals. Knowledge and understanding of the components of daily energy flow and the environmental factors that influence FMR will facilitate other kinds of studies that use energy as a currency in foraging, behavioral, and life-history analyses (Congdon et al. 1982; Congdon 1989).

We investigated RMRs and FMRs of free-living zebra-tailed lizards (Callisaurus draconoides) during seasons of reproduction and/or growth at two sites (one in the tropical zone and one in the temperate zone) in the arid southwest of North America. Because we previously studied the RMR and FMR of this species during a period of no production at one of these sites (Anderson and Karasov 1981), these studies together advance our knowledge of variation in lizard energetics. One goal was to test for variation in FMR among populations and understand its proximal causes. A second goal was to characterize energy flow at different points in the life cycle of individuals within a population. For example, our comparisons permit an investigation into the total contribution of all components of the energy cost of production rather than simply the energy in a clutch or new tissue, such as energy allocated to courtship, competition for mates, nesting, acquisition of extra food energy, and respiratory cost of production (Congdon et al. 1982; Nagy 1983a; Anderson and Karasov 1988). Comparisons within and between populations included measurements of metabolism in the field and under controlled conditions in the 
laboratory and observations on reproduction and behavior in the field. Combining laboratory and field measures in a single analysis allowed us to determine the physiological and behavioral correlates of the seasonal differences in FMR.

Callisaurus draconoides are insectivorous, ambush predators that occupy open, patchy desert scrub with a mix of soft- and hard-packed sandy substratum. They inhabit a wide range of desert scrub biomes, from the southern Great Basin Desert in southern Nevada south into the Sonoran Desert scrub to the cape region of Baja California and into the Chihuahuan desert of north-central Mexico. Over this range, populations differ in body size and in occurrence of the reproductive season (Pianka and Parker 1972; Tanner and Krogh 1975). We investigated the RMRs and FMRs of lizards at two sites. We then related the energetics to differences in body size and reproduction by considering the components of energy flow (energy budgets) and the sources of variability in energy flow in C. draconoides compared with those of other lizards.

\section{Material and Methods}

Study Sites

A portion of a population of Callisaurus draconoides in the Chuckwalla Valley of the Colorado Desert near Desert Center, Riverside County, California was studied from 1980 to 1986 during the months March-October. Vegetation on the 6-ha study site $(200 \times 300 \mathrm{~m})$ has been described in detail (Anderson 1993). In this area, winter rainfall (January-March) tends to be slightly greater and more predictable than summer rainfall (July-September) (Anderson 1993). Reproductive females were found (containing yolking follicles, oviductal eggs, or corpora lutea) during two distinct seasons, April-May and again in August-September (R. A. Anderson and W. H. Karasov, unpublished data), and females were nonreproductive in mid- to late June (Anderson and Karasov 1981).

The second study site is in the arid tropical cape region of Baja California near Cabo San Lucas (hereafter, Cabo) and was studied in August-September 1978 and 1979. The vegetation of this thorn scrub has been previously described (Karasov and Anderson 1984; the site was identified as the Ocean Bluff site). The region has relatively abundant late summer rainfall from mid-August to early October and less abundant and less predictable rainfall in mid-June to mid-August. Females were gravid and ovipositing during the study.

\section{Rates of Field Metabolism and Water Influx}

FMR and water influx rates were measured through the doubly labeled water (DLW) method (Anderson and Karasov 1981; Nagy 1983b). This is a widely used technique that has been tested and validated in three other species in the infraorder Inguania (Congdon et al. 1978; Nagy 1983b; van Marken Lichtenbelt et al. 1993) and is routinely assumed to be valid for lizards in xeric environments. As described previously (Anderson and Karasov 1981), lizards were captured and injected with labeled water and blood samples were taken (from the infraorbital sinus); then the lizards were weighed, released, and later recaptured for a final weighing and blood sample. For juveniles studied in August 1986 (mean mass = $1.8 \mathrm{~g}$ ), the initial blood sample was omitted and data were analyzed by the single-sample method, which also has been validated (Webster and Weathers 1989).

For each lizard (except juveniles), initial body water content was determined from the dilution of ${ }^{18} \mathrm{O}$. For the final body water content, each individual was assigned the average percent of body mass that was water in the initial group. For juveniles in August-September whose sex was unknown, we used a water content (73\% of mass) rounded up from the weighted average water content of the larger males $(73.7 \% \pm 0.5 \%, n$ $=14)$ and females $(71.3 \% \pm 0.7 \%, n=12)$ that were studied concurrently. Errors of $1 \%-2 \%$ in our estimates of body water translate into similar sized errors in calculated water flux and $\mathrm{CO}_{2}$ production (W. H. Karasov and R. A. Anderson, unpublished observations). Equation (2) of Nagy (1980) was used to calculate $\mathrm{CO}_{2}$ production, and equation (4) of Nagy and Costa (1980) was used to calculate water influx. $\mathrm{CO}_{2}$ production rates were converted from milliliters of $\mathrm{CO}_{2}$ per day to joules per day by means of the relationship $27.42 \mathrm{~J} \mathrm{~mL}^{-1} \mathrm{CO}_{2}$ (calculated for a fed, insectivorous lizard; Gessaman and Nagy 1988). Metabolic water of each lizard was calculated with the conversion factor $0.026 \mu \mathrm{L} \mathrm{J}^{-1}$ metabolized (Schmidt-Nielsen 1990).

\section{Environmental Conditions and Lizard Activity Patterns}

Observations of daily behavior patterns, body temperatures, and air and surface temperatures were made in order to interpret possible differences in FMR between sexes, sites, and seasons.

Temperatures of sunlit and shaded soil surfaces were measured hourly with a Wescor rapid-registering mercury thermometer. Soil temperatures greater than $50^{\circ} \mathrm{C}$ were measured with a standard $-10^{\circ}$ to $100^{\circ} \mathrm{C}$ glass-bulb mercury thermometer embedded horizontally in the top $0.25 \mathrm{~cm}$ of soil at an open sandy location for the duration of the DLW study. Hourly measurements of air temperatures were made with the Wescor thermometer at $1 \mathrm{~cm}$ and $1 \mathrm{~m}$ above both shaded and unshaded soil surfaces (with thermometer shaded from direct sun).

Lizards were noosed, and deep-cloacal temperatures were measured within $15 \mathrm{~s}$ with the Wescor thermometer. Body temperature $\left(T_{\mathrm{b}}\right)$ for a lizard was not measured if the individual fled prior to capture. Lizards were toe-clipped, painted with an identification color, and later released at the point of capture.

The relative level of activity of the population, that is, the apparent abundance of individuals during the morning and afternoon, was estimated in two ways. By one method, one to three people counted lizards while walking transects through each study area during morning (up to 1200 hours) and after- 
noon (1200 hours to dusk). By the other method, we measured the amount of time it took to find each consecutive lizard and then combined these search times into blocks of 1 personhour increments and expressed the data as number of lizards seen per person-hour searching during morning or afternoon. Time of first activity at each site was determined by checking at earlier hours (0630-0830 hours).

To study detailed behavior of individuals, we first searched by walking slowly and watching carefully for stationary lizards. Normally, a lizard was seen from 5 to $15 \mathrm{~m}$ distant, and if the lizard did not appear to be disturbed by the observer (either it did not flee or did not appear to watch or pay attention to the observer), then the lizard's behavior was recorded for the next $15 \mathrm{~min}$. A stopwatch was used to record time spent in movement; behavioral notes were written.

\section{Maintenance Metabolism}

In 1979, rate of $\mathrm{O}_{2}$ consumption $\left(\dot{\mathrm{V}}_{2}\right.$; at STP) of nonfasted $C$. draconoides from Cabo were obtained in the laboratory by direct manometric measures of $\mathrm{O}_{2}$ depletion with a singlevalve Gilson differential respirometer, as described previously for $C$. draconoides from Desert Center that were measured the same time (Anderson and Karasov 1981). Lizards were captured in early September (Mexican permit no. 87/906/79) and returned to the University of California, Los Angeles, where they were maintained in the laboratory on a $12 \mathrm{~L}: 12 \mathrm{D}$ photoperiod with a heat lamp to allow basking and fed mealworms and crickets ad lib. The measures of $\dot{\mathrm{O}}_{2}$ were made between September 25 and October 13. Some lizards may have become postreproductive by then, because the reproductive season seems to be largely in September in Cabo (no necropsies were performed). Some of the same lizards were used at different temperatures, and the temperatures were not applied to individuals in random order. The $\mathrm{Q}_{10}$ (rate of change for each $10^{\circ} \mathrm{C}$ change in temperature) was calculated for each individual for whom repeated measures were available. $\dot{V}_{2}$ was converted to energy using the relationship $20.1 \mathrm{~J} \mathrm{~mL}^{-1} \mathrm{O}_{2}$ (SchmidtNielsen 1990). Because the lizards were nonfasted, we considered these measures RMRs.

During the reproductive season in April 1982, $\dot{\mathrm{V}}_{2}$ of $C$. draconoides from Desert Center was measured in the laboratory in a closed system (Vleck 1987). The measurement procedures, involving lizards placed in syringe-like cylinders $(250-350 \mathrm{~mL}$ ) in a controlled-temperature room, with subsequent measures of $\mathrm{O}_{2}$ in gas samples on an Applied Electrochemistry $\mathrm{O}_{2}$ analyzer, have been described previously (Anderson and Karasov 1988). We assume (but did not test) that this method gives comparable results to those from the Gilson respirometer that we used in 1979. Nighttime $\dot{\mathrm{V}}_{2}$ at $30^{\circ} \mathrm{C}$ was measured for each lizard when nonfasted (called RMR) and when fasted (called standard metabolic rate, SMR; Bennett and Dawson 1976). We considered RMR to include SMR (the minimum maintenance metabolism at a particular $T_{\mathrm{b}}$ ) and the energy cost of digestion and anabolism of food energy. Our usual procedure was to capture lizards and fast them for $5 \mathrm{~d}$ in the laboratory, measure $\dot{\mathrm{V}}_{2}$, and then feed the lizards mealworms and crickets for $5 \mathrm{~d}$ ad lib. and measure $\dot{\mathrm{V}}_{2}$ once more. A shortcoming of this design was that the fasted and fed treatments were completely confounded with the time lizards were held in the laboratory and, hence, with potential acclimation effects. All RMR measurements were made with lizards that we had observed to have eaten on the morning of the day of measurement. Because feeding was ad lib., we may have been measuring the costs associated with production (either storage, growth, or reproduction) as well as RMR.

\section{Statistical Analyses}

Numerical results are given as mean \pm one standard error $(n$ $=$ number of lizards unless otherwise indicated). ANOVA, using the general linear model in SYSTAT (Wilkinson 1992), was used to test for differences according to sex, site (i.e., source population), reproductive status, season, or other grouping factors. The Tukey test was used to isolate differences when more than two groups were compared. Rates of change in body mass $\left(\% \mathrm{~d}^{-1}\right)$ were compared by using the arcsine of the square root of the proportional change per day. When body mass was included as a covariate in ANCOVA, the dependent variable (e.g., FMR, RMR, water influx) and body mass were first log transformed. Interactions between grouping factors and body mass were tested and removed if nonsignificant. Subsequent post hoc comparisons among grouping factors were made on the adjusted least squares means from the ANCOVA, as described in SYSTAT, which preserves the total variance in the entire data set when testing various hypotheses about differences by grouping factors. In the case of analysis of RMR, 20 of the 50 values analyzed were repeated measures made at different temperatures on the same individuals, but in the analysis all measures were treated independently. In the case of analysis of field $T_{\mathrm{b}}$ 's according to site, season, sex, and time of day, we followed the procedures recommended by Burnham and Anderson (1992) for selecting the most appropriate model. In brief, we calculated residual sums of squares for 53 models of observed temperature conditional on these four explanatory variables (certain two-way, three-way, and the four-way interactions were missing because of incomplete crossing of all factor levels) and used Mallow's $C_{\mathrm{p}}$ as the basis for objective model selection. The residuals from this model were approximately normally distributed. Model II reducedmajor-axis regression was used to test for correlation between growth rate and FMR of juvenile lizards. In all tests, the criterion of statistical significance was $P<0.05$.

\section{Results}

\section{Lizard Activity Patterns and Environmental Conditions}

We previously reported evidence that Callisaurus draconoides individuals tend to be active on a daily basis, at least during 
Table 1: Data used to estimate activity period lengths of Callisaurus draconoides

\begin{tabular}{|c|c|c|c|c|c|}
\hline Site & Season & $\begin{array}{l}\text { Time Activity } \\
\text { Began }^{\text {a }} \\
\text { (hours } \pm \text { min) }\end{array}$ & $\begin{array}{l}\text { Soil Surface } \\
\text { Temperature When } \\
\text { Activity Began } \\
\left({ }^{\circ} \mathrm{C}\right)\end{array}$ & $\begin{array}{l}\text { Time Activity } \\
\text { Ended }^{\mathrm{b}} \\
\text { (hours } \pm \mathrm{min} \text { ) }\end{array}$ & $\begin{array}{l}\text { Estimated } \\
\text { Activity } \\
\text { Period Length } \\
\text { (h) }\end{array}$ \\
\hline Desert Center ........ & April-May & $\begin{array}{l}0757 \pm 42 \\
(n=13)\end{array}$ & $\begin{array}{l}30.4 \pm 3.0 \\
(n=9)\end{array}$ & $\begin{array}{l}1717 \pm 36 \\
(n=7)\end{array}$ & 9.5 \\
\hline Desert Center ......... & May-June & $\begin{array}{l}0642 \pm 29 \\
(n=6)\end{array}$ & $\begin{array}{l}31.4 \pm 1.1 \\
(n=6)\end{array}$ & $1830-1840^{c}$ & 11.5 \\
\hline Desert Center ........ & August & $\begin{array}{l}0623 \pm 31 \\
(n=6)\end{array}$ & $\begin{array}{l}30.0 \pm 2.0 \\
(n=8)\end{array}$ & $1800^{c}$ & 11.5 \\
\hline 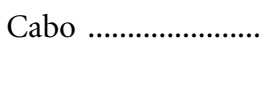 & August-September & $\begin{array}{l}0831 \pm 11 \\
(n=4)\end{array}$ & $\begin{array}{l}31.2 \pm 1.1 \\
(n=4)\end{array}$ & $1930^{c}$ & 11.0 \\
\hline
\end{tabular}

a Time of first sighting; $n=$ number of days.

b Time of last sighting; $n=$ number of days.

c Sundown.

the nonreproductive season in June (Anderson and Karasov 1981), and our new observations indicated the same for the spring reproductive season. In April 1980, we monitored two males and four females for 5 consecutive days each. We saw the males on 9 of 10 lizard-days, and the females on 19 of 20 lizard-days. We did not perform this systematic survey of daily activity during August at either Desert Center or Cabo.

First sightings of $C$. draconoides in the morning were earlier in summer months than in spring months and generally corresponded with when soil surface temperature was greater than or equal to $30^{\circ} \mathrm{C}$ (Table 1). The level of activity, as indexed by sightings per person-hour, was similar in the morning and afternoon, as previously reported for Desert Center in June (Anderson and Karasov 1981). For example, on mornings in April-May at Desert Center we observed 9.9 \pm 2.8 lizards per person-hour $(n=12 \mathrm{~d})$ and in afternoons $8.4 \pm 1.8(n=10$ d). In Cabo in August-September, we observed $3.1 \pm 0.8$ lizards per person-hour $(n=4 \mathrm{~d})$ during morning hours and $3.3 \pm 1.0(n=5 \mathrm{~d})$ during afternoon hours. In summertime at both sites, lizards remained active until sunset but ceased daily activity at somewhat earlier than sunset in springtime at Desert Center (Table 1). Depending on season and site, estimated activity period length ranged from 9.5 to $11.5 \mathrm{~h} \mathrm{~d}^{-1}$ (Table 1). Although the sample sizes for observations at Cabo and Desert Center are small, the observations were made on nonconsecutive days spread throughout the study periods, and the weather conditions on those days were representative. For example, during the $18 \mathrm{~d}$ of our study at Cabo, the weather conditions were relatively constant, with skies clear or hazy and warm temperatures all day, except for one day when skies were cloudy until 1430 hours (Karasov and Anderson 1984). Also, the conclusion about activity time from the limited systematic searches was in accord with our general impression made from working at Cabo for several weeks during a second field season and at Desert Center for many years.
We previously reported that, during the June nonreproductive season, C. draconoides spend less than $3 \%$ of their activity time in movement, with males exceeding females (Anderson and Karasov 1981). Our new measurements indicated the same trends for the April-May 1982 reproductive season. Males spent more time in movement ( $1.6 \%$ of activity time; 284 min of observation on 17 lizards) than did females $(0.9 \% ; 285$ min of observation on 19 lizards) and moved greater distances $(80 \mathrm{~m}$ per minute of moving) than did females ( $0.3 \mathrm{~m}$ per minute of moving). We observed more feeding attempts by females (2.9 attempts per hour of observation) than by males (1.1 attempts per hour). However, our time budget estimates are based on pooled data, and no statistical comparisons were performed.

During activity, C. draconoides maintained a $T_{\mathrm{b}}$ of $39^{\circ}-42^{\circ} \mathrm{C}$ (Table 2), with small, but significant differences according to site $\left(T_{\mathrm{b}}\right.$ was higher at Desert Center than at Cabo at all times of day; $\left.F_{1,109}=10.2 ; P=0.002\right)$, season $\left(T_{\mathrm{b}}\right.$ was highest in August; $\left.F_{1,109}=10.2 ; P=0.002\right)$, and time of day $\left(T_{\mathrm{b}}\right.$ was highest in midday; $\left.F_{2,109}=5.59 ; P=0.005\right)$. There was no significant difference according to $\operatorname{sex}\left(F_{1,109}=0.4 ; P=0.6\right)$. We previously reported that the field-active $T_{\mathrm{b}}$ of $C$. draconoides at Desert Center during June is $40.4^{\circ} \pm 1.5^{\circ} \mathrm{C}(n=42)$ (Anderson and Karasov 1981).

At the end of the activity period (usually sundown), $C$. draconoides bury themselves no more than $1 \mathrm{~cm}$ by wriggling into loose sand, usually in washes (Grenot et al. 1995; W. H. Karasov and R. A. Anderson, personal observations). Consequently, during the night we assumed that their $T_{\mathrm{b}}$ 's were equal to the soil surface temperature, which decreases from dusk to dawn (see Fig. 1 in Karasov and Anderson [1984]). This assumption is based on low evaporative water loss, and hence cooling, and a short thermal time constant, but these are reasonable assumptions for this small desert lizard. On the basis of measurements of soil surface temperature (at $5 \mathrm{~mm}$ depth in sand) at dusk in April-May (Anderson and Karasov 1988), 
Table 2: Mean field active $T_{\mathrm{b}}\left({ }^{\circ} \mathrm{C}\right)$ of Callisaurus draconoides

\begin{tabular}{|c|c|c|c|}
\hline \multirow[b]{2}{*}{ Time Block } & \multicolumn{2}{|c|}{ Desert Center } & \multirow{2}{*}{$\begin{array}{l}\text { Cabo } \\
\text { August-September }\end{array}$} \\
\hline & April-May & August & \\
\hline Before 1000 hours ............ & $\begin{array}{l}39.3 \pm .4 \\
(n=9)\end{array}$ & $\begin{array}{l}39.5 \pm .6 \\
(n=14)\end{array}$ & $\begin{array}{l}38.2 \pm .3 \\
(n=7)\end{array}$ \\
\hline 1001-1500 hours ................ & $\begin{array}{l}40.2 \pm .3 \\
(n=33)\end{array}$ & $\begin{array}{l}42.1 \pm .4 \\
(n=12)\end{array}$ & $\begin{array}{l}40.3 \pm .3 \\
(n=28)\end{array}$ \\
\hline 1501 and later & $\begin{array}{l}39.5 \pm .2 \\
(n=16)\end{array}$ & $\begin{array}{l}41.0 \pm .8 \\
(n=12)\end{array}$ & $\begin{array}{l}39.9 \pm .2 \\
(n=4)\end{array}$ \\
\hline
\end{tabular}

Note. Values are means $\pm \mathrm{SE} ; n=$ number of lizards.

June (Anderson and Karasov 1981), and August $\left(37.0^{\circ} \pm 4.0^{\circ} \mathrm{C}\right.$, $n=5 \mathrm{~d}), T_{\mathrm{b}}$ 's would be $40^{\circ} \mathrm{C}$ at dusk in Desert Center, but $33^{\circ} \mathrm{C}$ at dusk in Cabo (Karasov and Anderson 1984). At dawn in Desert Center in August, soil surface temperature and hence $T_{\mathrm{b}}$ was $26.0^{\circ} \pm 0.8^{\circ} \mathrm{C}(n=9 \mathrm{~d})$, very similar to dawn soil surface temperature of $27^{\circ} \mathrm{C}$ at other seasons and at Cabo (see previous references).

\section{Body Mass and FMR of Free-Living Callisaurus}

Our field measurements of mass change and $\mathrm{CO}_{2}$ production permit analyses for the effects of body mass, sex, site (i.e., source population), season, age, and reproductive status (Table 3 ).

Body Mass and Mass Change. Among the groups of Callisaurus listed in Table 3, there was significant variation in body mass $\left(F_{8,78}=26.2 ; P<0.001\right)$ and in rate of mass change $\left(F_{8,78}\right.$ $=11.28 ; P<0.001)$. Callisaurus were larger at Desert Center than at Cabo, and males were larger than females at both sites (Tukey comparisons; Table 3). Rates of mass change among groups of lizards were fairly similar, except that juveniles at Desert Center in August exhibited higher rates of mass gain than other cohorts $(P<0.001$ by Tukey test; Table 3$)$. Females in Cabo had higher rates of mass loss than females at Desert Center. This occurred because the Cabo females laid their eggs during the relatively short (7-d) release-recapture period.

Effects of Body Mass, Sex, Site, and Season on FMR. To test for correlates of FMR, we performed an ANCOVA on $\ln$ (FMR) and used the Tukey test and specific post hoc tests on adjusted least squares means of the groups shown in Table $3 . \operatorname{Ln}$ (mass) was a significant covariate of $\ln (\mathrm{FMR})\left(F_{1,75}=73.0 ; P\right.$ $<0.001$ ); there was no significant interaction between $\ln$ (mass) and group $\left(F_{8,67}=1.14 ; P=0.35\right)$; and the pooled slope was $0.85 \pm 0.10$ (Fig. 1). Group was a significant factor $\left(F_{8,75}\right.$ $=3.375 ; P=0.002)$. At Desert Center, FMR tended to be higher when measured later in the activity season. FMR for adults (males and females combined) was significantly higher in August-September compared with both April-May (post hoc contrast; $\left.F_{1,75}=16.14 ; P<0.001\right)$ and June $\left(F_{1,75}=5.34\right.$; $P=0.024)$, whereas the difference was not significant between June and April-May $\left(F_{1,75}=192 ; P=0.17\right)$. $\operatorname{Ln}(\mathrm{FMR}) \operatorname{did}$ not vary significantly with sex (all seasons; $F_{1,75}=1.1 ; P=0.3$ ) or site (August-September; $F_{1,75}=0.1 ; P=0.8$ ).

Effect of Age Class and Growth on FMR. Juvenile lizards had the highest least squares adjusted FMR, and a post hoc comparison between them and adults (males and females combined) at Desert Center in August also indicated a trend for higher FMR $\left(F_{1,75}=3.60 ; P=0.062\right)$.

As a further test for an effect of growth on FMR, we fit the data on the nine juveniles to the theoretically expected linear relationship between energy expenditure $(M)$ and growth $(G)$ : $M=m+c G$, where $c$ is the cost per unit of growth and $m$ is the maintenance expenditure at zero growth (Jorgensen 1988). We plotted energy expenditure in milliliters of $\mathrm{CO}_{2}$ per day against the rate of mass change in milligrams per day. The reduced-major-axis regression was significant $\left(t_{7}=2.84 ; P\right.$ $=0.014)$, and the slope of the relation was $0.338 \pm 0.119 \mathrm{~mL}$ $\mathrm{CO}_{2} \mathrm{mg}^{-1}$ growth.

Effect of Reproductive Status on FMR. We were able to compare gravid females (those with vitellogenic follicles or oviductal eggs, as determined by palpation) with others that appeared nonreproductive (nongravid and apparently had not previously laid eggs) during the April-May reproductive season (not shown in Table 2). Gravid females were significantly heavier than nonreproductive females (respectively, $10.16 \pm 0.48 \mathrm{~g}, n$ $=6$, vs. $6.45 \pm 1.11 \mathrm{~g}, n=4 ; P=0.009$ by one-way ANOVA) but did not differ significantly in mass change $(P=0.71)$. FMR was significantly higher (respectively; $54.2 \pm 5.7 \mathrm{~mL} \mathrm{CO}_{2}$ $\mathrm{d}^{-1}$ vs. $\left.30.8 \pm 8.2 ; P=0.05\right)$, probably because of the larger size. With $\ln$ (body mass) as a covariate, gravid females did not have significantly higher FMR than nonreproductive females $\left(F_{1,7}=0.001 ; P>0.9\right)$.

\section{Water Influx of Free-Living Callisaurus}

We tested for effects of mass, sex, site, season, age, and reproductive status on water influx using the same statistical procedures that we used for analyzing FMR. 
Table 3: Body mass, FMR, and water influx of free-living Calisaurus draconoides as a function of source population (site), season, and sex

\begin{tabular}{|c|c|c|c|c|}
\hline & $\begin{array}{l}\text { Mass } \\
(\mathrm{g})\end{array}$ & $\begin{array}{l}\text { Change in Mass } \\
\left(\% \mathrm{~d}^{-1}\right)\end{array}$ & $\begin{array}{l}\text { FMR } \\
\left(\mathrm{mL} \mathrm{CO}_{2} \mathrm{~d}^{-1}\right)\end{array}$ & $\begin{array}{l}\mathrm{H}_{2} \mathrm{O} \text { Influx } \\
\left(\mu \mathrm{L} \mathrm{d} d^{-1}\right)\end{array}$ \\
\hline \multicolumn{5}{|l|}{ Desert Center: } \\
\hline \multicolumn{5}{|l|}{ April-May (1980): } \\
\hline \multirow[t]{2}{*}{ 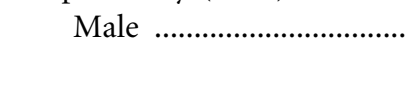 } & $10.44^{\mathrm{g}}$ & $-.19^{\mathrm{b}}$ & $48.7^{\mathrm{b}}$ & $179^{\mathrm{a}, \mathrm{b}}$ \\
\hline & $(.71,9)$ & $(.10,9)$ & $(3.4,9)$ & $(17,9)$ \\
\hline \multirow[t]{2}{*}{ Female } & $8.87^{\mathrm{d}, \mathrm{f}, \mathrm{g}, \mathrm{h}}$ & $-.32^{\mathrm{b}}$ & $42.5^{\mathrm{b}, \mathrm{c}, \mathrm{d}}$ & $168^{\mathrm{a}, \mathrm{b}}$ \\
\hline & $(.55,15)$ & $(.14,15)$ & $(4.2,15)$ & $(20,15)$ \\
\hline \multicolumn{5}{|c|}{ August-September (1986): } \\
\hline \multirow[t]{2}{*}{ Male …................................ } & $10.61^{\mathrm{g}}$ & $-.27^{\mathrm{a}, \mathrm{b}}$ & $59.0^{\mathrm{d}}$ & $260^{c}$ \\
\hline & $(.66,14)$ & $(.10,13)$ & $(3.9,12)$ & $(17,13)$ \\
\hline \multirow[t]{2}{*}{ Female } & $6.80^{\mathrm{b}, \mathrm{d}, \mathrm{c}, \mathrm{h}}$ & $-.21^{\mathrm{b}}$ & $43.2^{\mathrm{b}, \mathrm{c}, \mathrm{d}}$ & $198^{\mathrm{b}, \mathrm{c}}$ \\
\hline & $(.47,11)$ & $(.20,11)$ & $(3.9,11)$ & $(16,11)$ \\
\hline \multirow[t]{2}{*}{ Juvenile ............................... } & $1.83^{\mathrm{a}}$ & $+1.31^{\mathrm{c}}$ & $19.0^{\mathrm{a}}$ & $99^{\mathrm{a}}$ \\
\hline & $(.09,9)$ & $(.17,9)$ & $(1.2,9)$ & $(6,7)$ \\
\hline \multicolumn{5}{|l|}{ June (1979): } \\
\hline \multirow[t]{2}{*}{ 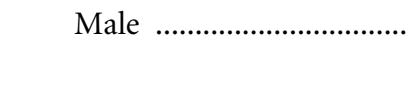 } & $11.62^{\mathrm{g}}$ & $-.27^{\mathrm{a}, \mathrm{b}}$ & $56.3^{\mathrm{c}}$ & $171^{\mathrm{a}, \mathrm{b}}$ \\
\hline & $(.92,6)$ & $(.08,6)$ & $(4.0,6)$ & $(12,6)$ \\
\hline \multirow[t]{2}{*}{ Female ............................... } & $7.38^{c, e, f}$ & $-.22^{\mathrm{b}}$ & $39.2^{\mathrm{b}, \mathrm{c}}$ & $134^{\mathrm{a}, \mathrm{b}}$ \\
\hline & $(.44,11)$ & $(.13,11)$ & $(2.2,11)$ & $(8,11)$ \\
\hline \multicolumn{5}{|l|}{ Cabo: } \\
\hline \multicolumn{5}{|l|}{ August-September (1978): } \\
\hline \multirow[t]{2}{*}{ Male } & $6.24^{\mathrm{c}, \mathrm{d}}$ & $-.82^{\mathrm{a}, \mathrm{b}}$ & $35.7^{\mathrm{a}, \mathrm{b}}$ & $159^{\mathrm{a}, \mathrm{b}}$ \\
\hline & $(.22,7)$ & $(.11,7)$ & $(2.5,7)$ & $(14,7)$ \\
\hline \multirow[t]{2}{*}{ Female ............................... } & $4.55^{\mathrm{a}, \mathrm{b}, \mathrm{c}}$ & $-2.04^{\mathrm{a}}$ & $34.9^{\mathrm{a}, \mathrm{b}, \mathrm{c}}$ & $224^{\mathrm{b}, \mathrm{c}}$ \\
\hline & $(.10,5)$ & $(.80,5)$ & $(2.8,5)$ & $(18,5)$ \\
\hline
\end{tabular}

Note. Values are means (SE, $n=$ number of lizards). Values within a column that share a common superscript are not significantly different by Tukey's test $(P<0.05)$. For change in mass, the Tukey test was performed on the arcsine of the square root of the proportional change per day. For FMR and water influx, this Tukey test was performed on untransformed data. A Tukey test on log-transformed FMR and water influx, adjusted for $\ln ($ mass), is presented in the Results section. Data for June 1979 were taken from Anderson and Karasov (1981).

Effects of Body Mass, Sex, Site, Season, and Age Class on Water Influx. $\operatorname{Ln}$ (mass) was a significant covariate of $\ln$ (water influx) $\left(F_{1,74}=21.8 ; P<0.001\right)$; there was no significant interaction between $\ln$ (mass) and the groups in Table $3\left(F_{8,66}=1.05 ; P\right.$ $=0.41$ ); and the pooled slope was $0.62 \pm 0.13$ (Fig. 2). Group was a significant factor $\left(F_{8,74}=7.15 ; P<0.001\right)$. Post hoc contrasts showed that $\ln$ (water influx) was significantly higher when measured in August-September than in either AprilMay $\left(F_{1,74}=24.2 ; P<0.001\right)$ or June $\left(F_{1,74}=28.0 ; P<0.001\right)$, paralleling a similar trend in FMR. Ln(water influx) did not vary significantly with site in August-September $\left(F_{1,74}=0.8\right.$; $P=0.4$ ) and did not vary significantly with sex (all seasons; $F_{1,74}=3.176 ; P=0.079$ ), although the Tukey test indicated that females had higher water influx than males at Cabo. A post hoc comparison between juveniles and adults (males and females combined) at Desert Center in August found no trend for higher water influx in the former group $\left(F_{1,74}=0.44 ; P\right.$ $=0.51)$, contrary to the situation for FMR.
Effect of Reproductive Status on Water Influx. There was no significant difference between gravid $(n=6)$ and nonreproductive females $(n=4)$ in water influx in April-May at Desert Center, whether compared in simple one-way ANOVA $(P$ $=0.14)$ or by ANCOVA $(P>0.7)$ (not shown in Table 3 ).

\section{Estimation of Feeding Rates of Free-Living Callisaurus}

Rate of water influx potentially can be used to calculate rate of food intake (Nagy 1975; Anderson and Karasov 1981). The water influx rate measured with labeled hydrogen includes influx due to ingestion of free (preformed) water in food by drinking and/or vapor, and production of water by catabolism of fats, carbohydrates, and proteins (i.e., metabolic water, 0.026 $\mu \mathrm{L} \mathrm{J}^{-1}$ metabolized). Metabolic water production calculated from FMR ranged from $11 \%$ to $23 \%$ of total influx in lizards at both sites over all dates.

Metabolizable energy intake rates (or assimilation) of adult 


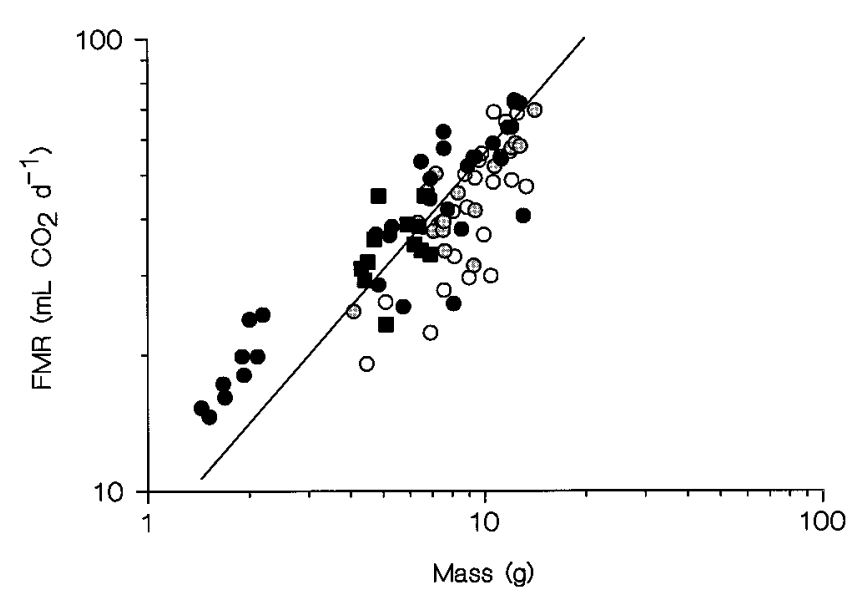

Figure 1. Relationship between FMR and body mass in Callisaurus draconoides. Lizards at Desert Center are represented by circles; those from Cabo San Lucas by squares. Open symbols are for April-May, lightly filled are for June, and filled symbols are for August-September. The group of nine lizards at low mass are juveniles from Desert Center; all others are adults. Sexes are not shown separately because they did not differ significantly in massadjusted FMR (see Results). ANCOVA (see Results) indicated that the only significant difference was due to season, in intercept but not slope. The solid line is the ANCOVA model for FMR as a function of body mass for all the data: FMR $=7.822$ body mass ${ }^{0.852}$.

males and females at Desert Center were calculated from water turnover data in two different ways, which were in close agreement. The first method took advantage of the fact that males were essentially in mass steady state during the labeled water studies in April-May and in August-September (Table 3). Assimilation in these males could be taken to equal their energy expenditure, and their ratio of FMR to apparent food water influx was then multiplied by the apparent food water influx of females to calculate the females' assimilation. This technique assumed that the two sexes had similar diets, and similar drinking or vapor influx in the case that they occur. The ratios ( $\mu^{-1}$ apparent water influx) for April-May and AugustSeptember were $9.3 \pm 0.5(n=9)$ and $7.4 \pm 0.6(n=11)$, respectively $\left(t_{18}=2.2 ; P=0.041\right)$. Estimated assimilation of females was $1,270 \mathrm{~J} \mathrm{~d}^{-1}$ for April-May and 1,237 $\mathrm{J} \mathrm{d}^{-1}$ for August-September.

In the second method, apparent food water influx rates of lizards were divided by the average water content of the diet. We assumed that no drinking or vapor influx occurred and that arthropod prey had an average water content of $70 \%$ (= $2.34 \mathrm{~mL} \mathrm{~g}^{-1}$ dry mass; Edney 1977; Anderson and Karasov 1988; Christian et al. 1995) and a chemical potential energy content of $23 \mathrm{~kJ} \mathrm{~g}^{-1}$ dry mass, of which about $75 \%$ was metabolizable (Harwood 1979). Hence, the ratio of metabolizable en-

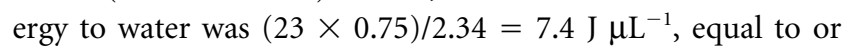
below the ratios estimated above. Estimated assimilation of females was 1,036 $\mathrm{J} \mathrm{d}^{-1}$ for April-May (18\% below method 1) and $1,237 \mathrm{~J} \mathrm{~d}^{-1}$ for August-September (same as method 1). Estimated assimilation for males was $1,066 \mathrm{~J} \mathrm{~d}^{-1}$ for April-
May and $1,584 \mathrm{~J} \mathrm{~d}^{-1}$ for August-September. By both methods 1 and 2, assimilation of subadults in August-September would be $635 \mathrm{~J} \mathrm{~d}^{-1}$, assuming that they have the same diet as adults. In the Discussion, we incorporate these estimates of assimilation into energy budgets of the different sex and age classes.

\section{$S M R$ and $R M R$}

Our measurements of $\mathrm{O}_{2}$ consumption of fed resting lizards (RMR) and fasted resting lizards (SMR) permit analyses for the effects of body mass, sex, site (i.e., source population), reproductive status (i.e., season), temperature, and fasting on resting energy expenditure.

Effects of Body Mass, Site, Sex, Reproductive Status, and Temperature on $R M R$. We compared 50 measures of RMR divided among 14 distinct groups: eight groups were the males and females from Cabo measured after the reproductive season at four temperatures, four were the males and females from Desert Center measured after the reproductive season at two temperatures, and the last two groups were the males and females from Desert Center measured during the reproductive season at one temperature. To test for correlates of RMR, we performed an ANCOVA on $\ln (\mathrm{RMR})$ and used specific post hoc tests on adjusted least squares means of the groups. There was no significant interaction between $\ln$ (mass) and group $\left(F_{13,22}\right.$ $=1.0 ; P=0.51) ; \ln$ (mass) was not a significant covariate of $\ln (\mathrm{RMR})\left(F_{1,35}=2.77 ; P=0.11\right)$; and there was significant

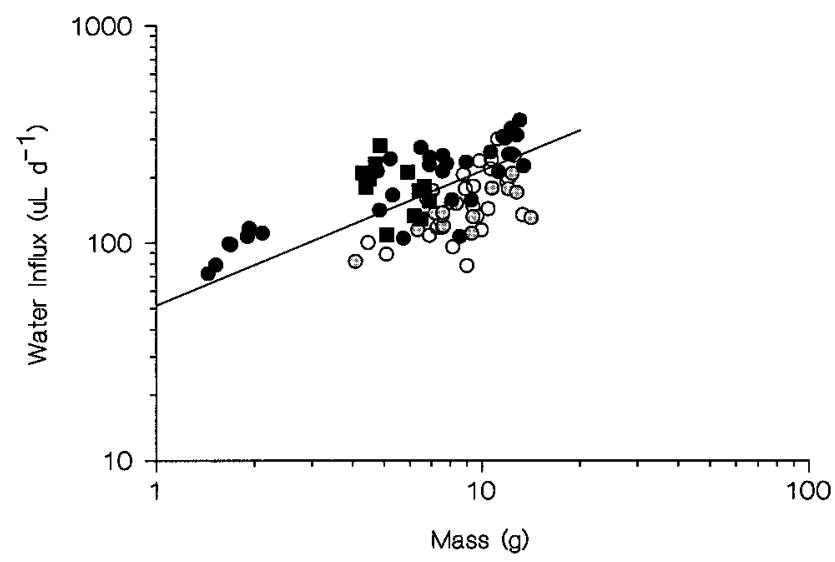

Figure 2. Relationship between water influx and body mass in Callisaurus draconoides. Lizards at Desert Center are represented by circles; those from Cabo San Lucas by squares. Open symbols are for April-May, lightly filled are for June, and filled symbols are for August-September. The group of seven lizards at low mass are juveniles from Desert Center; all others are adults. Sexes are not shown separately because they did not differ significantly in mass-adjusted water influx, except possibly in one case (see Results). ANCOVA (see Results) indicated that the only significant difference was due to season, in intercept but not slope. The solid line is the ANCOVA model for water influx as a function of body mass for all the data: water influx $=51.5$ body mass ${ }^{0.62}$. 


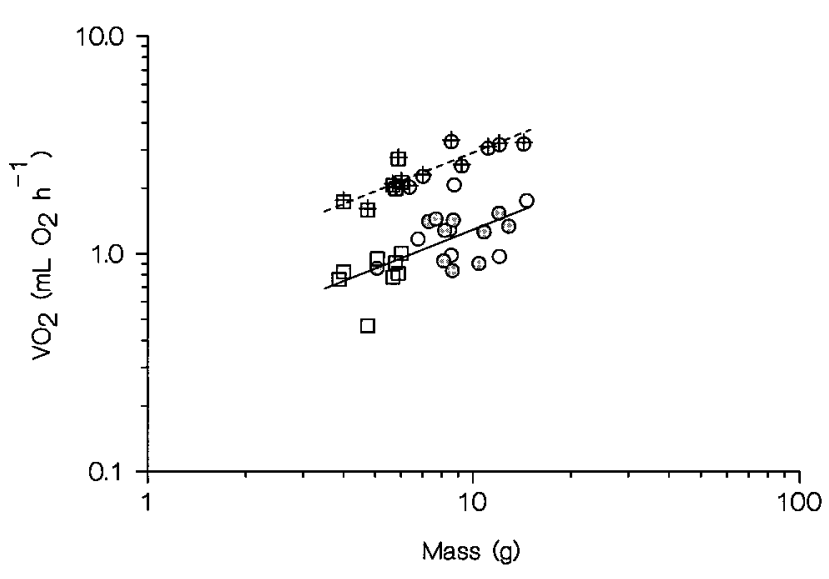

Figure 3. Relationship between resting $\dot{\mathrm{V}}_{2}$ of fed Callisaurus draconoides and body mass at two temperatures. Twenty lizards (10 male, 10 female) at Desert Center are represented by circles, and eight ( 5 male, 3 female) from Cabo San Lucas are represented by squares. Unfilled symbols represent lizards collected during the reproductive season (April-May for Desert Center, August-September for Cabo), and filled symbols represent lizards collected during the nonreproductive season (June at Desert Center; from Anderson and Karasov 1981). Cross-hatched symbols represent measures made at $40^{\circ} \mathrm{C}$, and those lacking cross-hatches are measures made at $30^{\circ} \mathrm{C}$. When these data were grouped by temperature, $\ln$ (mass) was a significant covariate of $\ln \left(\dot{\mathrm{V}}_{2}\right)\left(F_{1,37}=37.9\right.$; $P<0.001)$, and the relationships between $\ln$ (mass) and $\ln \left(\dot{\mathrm{V}}_{2}\right)$ at each temperature did not differ significantly in slope. When fitted to the common slope (0.594), the proportionality coefficients (intercepts at unity) for $30^{\circ}$ and $40^{\circ} \mathrm{C}$ were, respectively, 0.328 and $0.743 \mathrm{~mL} \mathrm{~h}^{-1}$, and were significantly different $\left(F_{1,37}=188 ; P\right.$ $<0.001)$. Note that 12 of the 40 data points represent repeated measures (at different temperatures) on the same individuals.

variation among the 14 groups $\left(F_{13,35}=20.7 ; P<0.001\right)$. Post hoc comparisons were not significant for sex at both sites $\left(F_{1,35}=0.22 ; P=0.64\right)$ or for reproductive status at Desert Center $\left(F_{1,35}=2.31 ; P=0.14\right)$, whereas variation was quite apparent for temperature (Fig. 3).

A total of 26 measures of RMR were made at four temperatures in six male and four female $C$. draconoides collected at Cabo (5.01 \pm 0.29 g) (Fig. 4). In cases in which repeated measures were made on the same individual, the $\mathrm{Q}_{10}$ between $25^{\circ}$ and $35^{\circ} \mathrm{C}$ was $2.83 \pm 0.09(n=2$ males, 2 females $)$ and between $30^{\circ}$ and $40^{\circ} \mathrm{C}$ was $2.64 \pm 0.25$ ( $n=4$ males, 2 females).

Callisaurus from Desert Center did not differ significantly from those at Cabo when RMR was measured at $40^{\circ} \mathrm{C}$ (post hoc comparison $F_{1,35}=0.92 ; P=0.34$ ) but had higher RMR when measured at $30^{\circ} \mathrm{C}$ (post hoc comparison $F_{1,35}=4.81 ; P$ $=0.035$ ). That statistical analysis, however, was based on RMR measurements made in different years, using different measurement methods, and in different seasons in a nonrandomized design, and it included some repeated measures on some individuals. Arguably, the variance structure might have differed for the subset of data that included only those independent measurements made using the same methodology at the same time. ANCOVA using this subset (six or seven males and females from Desert Center and nine or seven males and females from Cabo) revealed no significant difference between sites at either $30^{\circ} \mathrm{C}\left(F_{1,12}=1.59 ; P=0.23\right)$ or $40^{\circ} \mathrm{C}\left(F_{1,11}\right.$ $=0.05 ; P>0.8)$. By our most rigorous test, therefore, there was no significant difference between Callisaurus from the two sites in RMR.

Effect of Fasting. Fed and fasted lizards at Desert Center were tested at $30^{\circ} \mathrm{C}$ (fasted lizards not shown in Figs. 3 or 4 ). Repeated-measures ANOVA showed that lizards had significantly lower oxygen consumption when fasted than when fed $\left(F_{1,6}\right.$ $=22.9 ; P=0.003)$, with no significant interaction with sex $(P=0.63)$. The mean ratio of RMR to SMR was $1.220 \pm 0.041$ $(n=7)$.

\section{Discussion}

A notable result of our study was that most differences in whole-animal metabolism were mediated through differences in body mass or temperature. There was no significant effect of sex or source population on mass-adjusted FMR, RMR, or water influx. Also, the FMRs and water influx rates of juvenile lizards and gravid females were not significantly different from those of nonreproductive adults, after adjusting for differences in body mass. The slope of the relation between $\ln$ (metabolism) and $\ln$ (body mass) was $0.85 \pm 0.10$ for FMR. The scaling of FMR within Callisaurus appears similar to the scaling for FMR among lizard species (0.8; Nagy 1982). The scaling for water influx (mass exponent $0.62 \pm 0.13$ ) was lower than for FMR, which appears also to be the case for the interspecific scaling of water influx in reptiles (mass exponent $=0.69$; Nagy and Peterson 1988). For RMR, we found a trend (Fig. 3), but no statistically significant relationship, between metabolism and body mass. Besides the usually significant effect of body mass on metabolism, we saw that temperature had a significant effect

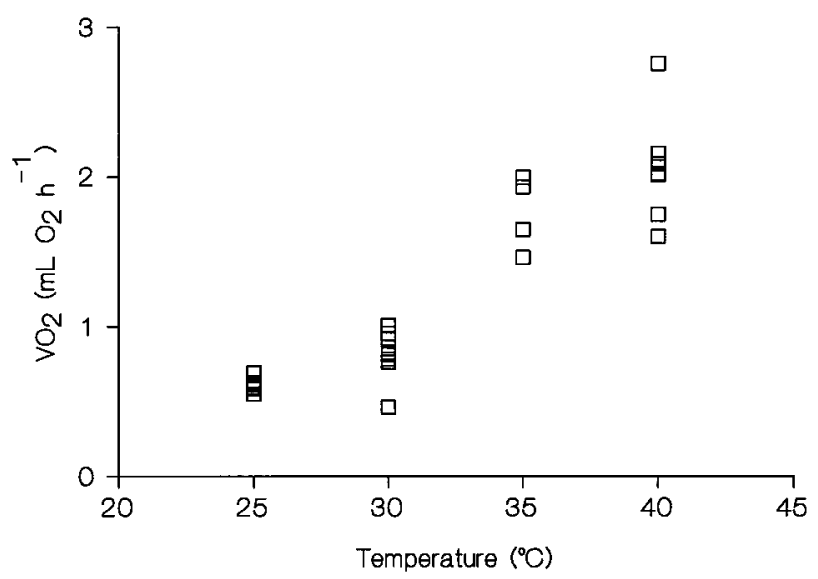

Figure 4. Relationship between resting $\dot{\mathrm{V}}_{2}$ and $T_{\mathrm{b}}$ of fed Callisaurus draconoides from Cabo San Lucas. Each unfilled square represents a measure on a lizard ( $n=10$ lizards). 
on $\mathrm{RMR}\left(\mathrm{Q}_{10}\right.$ ranged from 2.6 to 2.8 , depending on temperature range), fed lizards had RMR $22 \%$ higher than fasted lizards, and FMR increased 24\%-30\% (depending on sex) from spring to late summer at Desert Center.

In the following sections, we discuss these findings in relation to theoretical expectations and empirical findings elsewhere. One point that emerges is that the effects of production on metabolism are relatively small a priori, and that this is reflected in mixed empirical findings on the energetic cost of production. Then we discuss the results within the broader context of the ecological energetics of Callisaurus.

\section{Cost of Reproduction}

The maintenance metabolism of a female lizard that is producing eggs would, a priori, be expected to be higher than that of a nonreproductive female. Callisaurus produce a clutch (average 4.4 eggs) with $25.7 \mathrm{~kJ}$ total egg energy in about $50 \mathrm{~d}$ (Anderson and Karasov 1988). Assuming a cost per unit production of $0.33 \mathrm{~J}$ for production of $1 \mathrm{~J}$ of egg energy from food energy (Parry 1983; Jorgensen 1988), the biosynthesis of the clutch adds $8.5 \mathrm{~kJ}$ to the lizard's heat production, or 0.17 $\mathrm{kJ} \mathrm{d}^{-1}$. This would increase the RMR at $30^{\circ} \mathrm{C}$ of a $7.5-\mathrm{g}$ female by $21 \%\left(0.8 \mathrm{~kJ} \mathrm{~d}^{-1}\right)$. This is probably an overestimate of the effect, because, if most of the egg energy comes from transfer from fat depots, as appears to be the case (below), the partial efficiency would be higher and consequently the impact on RMR lower. We lack the statistical power for demonstrating such a small difference in RMR. Considering the variation in RMR ( $\mathrm{SD}=0.3 \mathrm{~mL} \mathrm{~h}^{-1}$ ), we can discriminate a difference between gravid and nongravid females of 33\% $\left(0.44 \mathrm{~mL} \mathrm{~h}^{-1}\right)$ using sample size of six per group, an $\alpha=0.1$ (one-tailed test for a priori expectation), and a power of $0.8(\beta=0.2)$ (Zar 1974). Therefore, it is not surprising that we found no significant difference between gravid and nongravid females in RMR with smaller sample sizes.

We have also been unable to measure a difference in RMR between reproductive and nonreproductive Cnemidophorus tigris (Anderson and Karasov 1988). In the literature, results are mixed with regard to effects of gravidity on lizard resting metabolism (reviewed in Beaupre et al. [1993]). This is perhaps consistent with insufficient power in some studies to detect a relatively small effect.

Factors that might increase metabolism of free-living gravid females over that of nonreproductive females include higher locomotion cost per meter due to greater mass, or more foraging to gain the extra energy for biosynthesis. Considering that female Callisaurus are ambush predators and move only a few meters per day (see Results, Lizard Activity Patterns and Environmental Conditions), and that feeding rates estimated from water influx were not higher in reproductive females compared with nonreproductive females (above), the impact of these factors would be small.

In contrast to our finding, it has been estimated that FMR increases in reproductive females, compared with nonreproductive females, by $100 \%$ in Uta stansburiana (Nagy 1983a) and by $17 \%$ in C. tigris (Anderson and Karasov 1988). In those species, it was also estimated for males that FMR (but not $\mathrm{RMR}$ ) is elevated for reproduction by $47 \%$ for Uta and by $43 \%$ for C. tigris. In Callisaurus, for the sites and seasons measured, we doubt that differences of this magnitude existed, for four reasons. First, although FMR of both male and female Callisaurus was higher during the August-September reproductive season compared with the June nonreproductive season, FMR during the April-May reproductive season was lower than that in June. Second, we had the statistical power to detect differences of those magnitudes. Third and fourth, our behavioral observations and laboratory respirometry did not reveal any causal bases for such a difference between reproductive and nonreproductive females. We ascribe the 24\%-30\% higher FMR in August-September compared with April-May to differences in activity period length and differences in $T_{\mathrm{b}}$ (below).

\section{Cost of Growth}

Metabolism should also be higher in growing lizards. On the basis of measured growth rates (Table 3 ) and the energy density of Callisaurus tissue $\left(4.99 \mathrm{~J} \mathrm{mg}^{-1}\right.$ wet tissue; Anderson and Karasov 1988), we estimated that juveniles deposited energy into new tissue at a rate of $120 \mathrm{~J} \mathrm{~d}^{-1}$ (see Implications for Ecological Energetics, below). With the assumption that the energetic cost of growth is equivalent to about one-third of the energy in the body mass deposited (Parry 1983; Jorgensen 1988 ), production in juveniles would account for about $40 \mathrm{~J}$ $\mathrm{d}^{-1}$, or about $8 \%$ of their total respiration $\left(521 \mathrm{~J} \mathrm{~d}^{-1}\right)$. If we consider this magnitude and the statistical power of our comparisons (above), it is perhaps not surprising that the FMR of juvenile Callisaurus was not significantly different from that of adults, after adjusting for difference in body mass. FMR of juveniles is also not significantly higher than that of adults for lizards in the genus Gallotia, although a trend was reported (Vernet et al. 1995).

Using the theoretically expected cost-of-growth model, we discriminated a correlation between FMR and growth rate in juvenile Callisaurus. The slope of the relation $(0.338 \pm 0.119$ $\mathrm{mL} \mathrm{CO} \mathrm{mg}^{-1}$ mass gain) converts to an apparent energetic cost of growth of $1.9 \mathrm{~J} \mathrm{~J}^{-1}$ deposited in tissue (95\% confidence interval $=0.31-3.4)$. This estimated energetic cost is referred to as apparent because it is not adjusted for costs of maintenance of increased body mass during the measurement period. This value is consistent with similarly calculated energetic costs of growth determined in captive vertebrate poikilotherms (range, 0.32-0.55 J J ${ }^{-1}$ deposited in tissue; Parry 1983; Jorgensen 1988). Our finding in Callisaurus is also consistent with the finding that in free-living U. stansburiana, FMR is positively correlated with rate of mass gain (Nagy 1983a) and the calculated apparent energetic cost of mass gain is greater than 1 . 
Variation among Populations

Body sizes of breeding Callisaurus are 33\%-45\% smaller in Cabo than in Desert Center (Table 3). By our most rigorous statistical test, males and females from the two populations do not differ significantly by site in RMR. Hence, whatever evolutionary or environmental factor(s) was responsible for the size difference (R. A. Anderson and W. H. Karasov, unpublished data.), it apparently had little effect on mass-specific resting metabolism. There are precedents for population differences in lizard resting metabolism over a latitudinal gradient (e.g., Sceloporus occidentalis; Tsuji 1988). Populations of S. occidentalis (Heusner and Jameson 1981) and Sceloporus merriami (Beaupre et al. 1993) at different altitudes do not differ significantly in resting metabolism, but in another study of rattlesnakes collected at the same sites as the $S$. merriami, the relationship between mass and resting metabolism is site-dependent (Beaupre 1993).

Given the lack of interpopulation difference in resting metabolism of Callisaurus, the fact that overall behavior, activity period length (Table 1), and body temperature regulation (Table 2) were similar in the two populations, and the apparently low genetic variation among Callisaurus draconoides populations (Adest 1987), it is not surprising that mass-specific field metabolism was similar in the two populations. We identified only one factor that might have caused a difference. Measures of soil temperature indicated that resting-period $T_{\mathrm{b}}$ 's would be near $40^{\circ} \mathrm{C}$ at dusk at Desert Center, but $33^{\circ} \mathrm{C}$ at dusk at Cabo (Karasov and Anderson 1984). The difference may last for only a few hours, and a slightly lower dawn soil temperature in August-September at Desert Center than at Cabo (above) may reduce the differences in temperature-related field metabolism that exist early in scotophase.

We are aware of only three other interpopulation comparisons of FMR in lizards, and all involve interpopulation body size differences as did our study. In a result much like ours, skinks (Chalcides sexlineatus) from a northern population on the subtropical Canary Island of Gran Canaria have larger (64\%) mean size than those from a southern population and have higher FMR on a whole-animal basis but not when adjusted for the difference in body mass (Brown et al. 1992). In the other two studies, interpopulation differences were reported for mass-adjusted FMR. In the Mediterranean, Podarcis lilfordi (Lacertidae) inhabiting an island at low density are 63\% larger, but have lower mass-adjusted FMR (by 24\%), than those inhabiting an island at higher density (Brown and PerezMellado 1994). The causal basis of this difference was not determined but was thought to lie either in differences in RMR or in differences in food acquisition costs. Finally, Cnemidophorus hyperythrus (Teidae) at a woodland site at Cabo San Lucas, Mexico, are 13\% larger and have 55\% higher mass-adjusted FMR than those at a scrub site (Karasov and Anderson 1984). There is evidence that the causal basis of this difference is longer activity periods at the woodland site, but a difference in RMR cannot be ruled out.
Establishing the causal basis for an observed interpopulation difference in FMR still leaves unresolved its persistence. All four interpopulation comparisons should be interpreted cautiously because they were not replicated over time. As discussed in the next section, considerable variation can occur within a population over time in FMR and feeding rate. Furthermore, our findings for two populations of Callisaurus hold only for resting and field metabolism; differences may occur in other features of the populations' ecological energetics, such as rates of growth or reproduction (R. A. Anderson and W. H. Karasov, unpublished data).

\section{Seasonal Effects on Metabolism}

Data on seasonal variation in field energetics of lizards in the cape region of Baja are scarce, but preliminary data (Grenot et al. 1995) suggest that there may be an annual period of inactivity during the four-month dry season (March-June) somewhat analogous to the annual period of inactivity at Desert Center from November through February. A visit by us to Cabo in March 1986 revealed few Callisaurus and none that could have been reproductive. Our study of seasonal variation in FMR and water influx at Desert Center does not take into account the likely very large decreases that can occur during annual periods of inactivity (Congdon et al. 1982; Nagy 1983a; Christian and Green 1994; Christian et al. 1995).

During the annual period of activity, FMR of Callisaurus at Desert Center increased about $24 \%-30 \%$ (depending on sex) from the spring reproductive season to the late summer reproductive season (see Results, Effects of Body Mass, Sex, Site, and Season on FMR). The seasonal difference might be due to proportionally more days active during the late summer measurement period, a higher rate of metabolism per hour during the active and/or inactive periods during late summer, and a longer daily activity period during late summer. The first explanation is unlikely, as lizards were probably active every day in springtime (93\% of 30 lizard-days checked; see Results, Lizard Activity Patterns and Environmental Conditions). The second explanation is partly supported by our finding that field-active $T_{\mathrm{b}}$, and hence RMR, was slightly higher in late summer (Table 2). A $1{ }^{\circ} \mathrm{C}$ difference would result in a $10.4 \%$ difference in metabolism, based on our measured $\mathrm{Q}_{10}$ of 2.7 (Fig. 4). Also, water influx, and thus feeding rate, was $40 \%$ higher in August than April, and some of the metabolic increment may be associated with higher cost of digestion and assimilation. If we assume that this cost is between 5\% (Beaupre et al. 1993) and 20\% (see Results, SMR and RMR, Effect of Fasting) of assimilation, which is $40 \%$ higher in August, the metabolic increment might be 2\%-8\%. Of likely greater energetic significance was the $20 \%$ longer activity period length (Table 1), especially because Callisaurus's rate of expenditure while active is 50\% higher than during inactivity (Anderson and Karasov 1981). A positive relation between FMR and activity period length has been reported in other waitambush (Merker and Nagy 1984) and wide-foraging (Anderson 
Table 4: Energy budgets of reproducing and growing Callisaurus draconoides at Desert Center

\begin{tabular}{|c|c|c|c|c|}
\hline Sex/Size Class & Time of Year & $\begin{array}{l}\text { Body Mass } \\
(\mathrm{g})\end{array}$ & $\begin{array}{l}\text { Assimilation }^{\mathrm{a}} \\
\left(\mathrm{J} \mathrm{d}^{-1}\right)\end{array}$ & $\begin{array}{l}\text { Respiration }{ }^{\mathrm{b}} \\
\left(\mathrm{J} \mathrm{d}^{-1}\right)\end{array}$ \\
\hline Female ............ & April-May & 10.4 & $\begin{array}{l}1,153 \\
\quad(840-1,466)\end{array}$ & $\begin{array}{l}1,165 \\
(917-1,413)\end{array}$ \\
\hline Female ............ & August-September & 6.8 & $\begin{array}{l}1,237 \\
(1,000-1,474)\end{array}$ & $\begin{array}{l}1,184 \\
(942-1,426)\end{array}$ \\
\hline Juvenile ........... & August-September & 1.8 & $\begin{array}{l}635 \\
(527-743)\end{array}$ & $\begin{array}{l}521 \\
(443-599)\end{array}$ \\
\hline
\end{tabular}

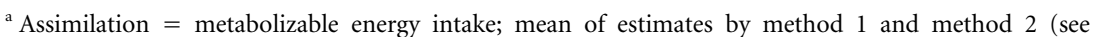
Results). Values in parentheses are the $95 \%$ confidence interval, calculated from the SE of the water influx in Table 3.

${ }^{\mathrm{b}}$ Respiration calculated from $\mathrm{CO}_{2}$ production (see Material and Methods). Values in parentheses are the $95 \%$ confidence interval, calculated from the SE of the value from the $\mathrm{CO}_{2}$ production in Table 3 .
}

and Karasov 1988) lizards. Seasonal differences in resting metabolism have been documented in some lizards (Tsuji 1988), but we infer from our results (Fig. 3) that seasonal differences in resting metabolism did not occur in the Callisaurus that we studied.

Seasonal (or annual) differences in FMR and feeding rate are not unusual in lizards and are typically associated with seasonal variation in environmental conditions that, in turn, influence $T_{\mathrm{b}}$ or activity patterns (Nagy 1983a; Mautz and Nagy 1987; Anderson and Karasov 1988; Bradshaw et al. 1991; Christian et al. 1995; Grenot et al. 1995). It is interesting that studies that document little or no significant seasonal variation in FMR (van Marken Lichtenbelt et al. 1993; Vernet et al. 1995) were performed in tropical/subtropical environments, where seasonal climate differences are perhaps attenuated. But even tropical habitats can exhibit large seasonal climate differences with correlated large seasonal differences in field metabolism (Christian and Green 1994).

\section{Implications for Ecological Energetics}

Our results offer insights into patterns of energy allocation in C. draconoides. We can determine the proportion of the lizard's energy budget allocated to growth and reproduction and deduce to what extent females during egg production rely on fat reserves versus daily energy intake.

Production energy devoted to growth by juveniles during August-September at Desert Center was estimated by two methods that gave results in close agreement. In the first method, we subtracted the expenditure for respiration from the estimated assimilation (Table 4), yielding production energy for growth of $114 \mathrm{~J} \mathrm{~d}^{-1}$. In the second, we multiplied the rate of mass gain $\left(24 \mathrm{mg} \mathrm{d}^{-1}=1.31 \% \mathrm{~d}^{-1} \times 1.83 \mathrm{~g}\right.$; Table 3 ) by the energy density of Callisaurus tissue $\left(4.99 \mathrm{~J} \mathrm{mg}^{-1}\right.$ wet tissue; Anderson and Karasov 1988), yielding an estimate of production energy for growth of $120 \mathrm{~J} \mathrm{~d}^{-1}, 5 \%$ higher. The net production efficiency $(100 \times$ production energy divided by assimilation) of growing $C$. draconoides is thus estimated to be $18 \%$. This is somewhat higher than estimated previously for five other species of small insectivorous iguanid lizards during the first year of their life (range, 7.5\%-16\%; Congdon et al. 1982; Nagy 1983a). Poikilothermic animals in general, including invertebrates, have net production efficiencies that average about 30\% (Peters 1983).

A key question is whether females meet the demands of egg production from food collected during the yolking of follicles in the weeks prior to laying or from fat stored up prior to the reproductive season. Lizards have been found to vary in this regard. For example, reproductive season production rates of C. tigris at Desert Center appear to account for all the energy in their clutches (Anderson and Karasov 1988), whereas up to $25 \%$ of the energy in one clutch of $U$. stansburiana is derived from fat stores rather than from recently collected food (Nagy 1983a).

Our estimates of feeding rate (and hence assimilation) from water influx data (above) were equal to or only slightly greater than the FMRs of females in both April and August (Table 4), implying that females must have stored the energy well before the time of laying. Females in August, for example, lay an average clutch of 4.2 eggs (R. A. Anderson and W. H. Karasov, unpublished data) with an energy content of $6.68 \mathrm{~kJ} \mathrm{egg}^{-1}$ (Anderson and Karasov 1988). Our estimate of their daily energy available for production, $52 \mathrm{~J} \mathrm{~d}^{-1}$ (Table 4 ), was only $10 \%$ of the estimated rate of energy deposition into eggs (above). Hence, we conclude that females deposited energy in fat stores well in advance of the reproductive season and probably lost considerable mass between the time before the first clutch in springtime and after the second clutch in September. Presumably, the months of September to hibernation, and hibernation to mid-April (a combined period of 4-5 mo) are a time of considerable mass gain in the females, preparing them for an activity season during which they suffer a net mass loss. 


\section{Acknowledgments}

Financial assistance was received from a National Research Service Award Training Grant GM 07191 to W.H.K., contract DE-AC03-76-SF00012 between the U.S. Department of Energy and the University of California (K. A. Nagy, principal investigator), National Science Foundation grant BSR8452089 to W.H.K., the University of California, Los Angeles, Graduate Division, the A. W. Schorger Fund, and the Max McGraw Wildlife Foundation. We are grateful to C. Karasov, S. James, and R. Chacon for field assistance.

\section{Literature Cited}

Adest G.A. 1987. Genetic differentiation among populations of the zebra-tail lizard Callisaurus draconoides (Sauria: Iguanidae). Copeia 1987:854-859.

Adolph S.C. and W.P. Porter. 1993. Temperature, activity, and lizard life histories. Am. Nat. 142:273-295.

Anderson R.A. 1993. Analysis of foraging in a lizard, Cnemidophorus tigris: salient features and environmental effects. Pp. 83-116 in J.W. Wright and L.J. Vitt, eds. Biology of Whiptail Lizards (Genus Cnemidophorus). Oklahoma Museum of Natural History, Norman, Okla.

Anderson R.A. and W.H. Karasov. 1981. Contrasts in energy intake and expenditure in sit-and-wait and widely foraging lizards. Oecologia 49:67-72.

-1988. Energetics of the lizard Cnemidophorus tigris and life history consequences of food-acquisition mode. Ecol. Monogr. 58:79-110.

Andrews R.M. and F.H. Pough. 1985. Metabolism of squamate reptiles: allometric and ecological relationships. Physiol. Zool. 58:214-231.

Beaupre S.J. 1993. An ecological study of oxygen consumption in the mottled rock rattlesnake, Crotalus lepidus lepidus, and the black-tailed rattlesnake, Crotalus molossus molossus, from two populations. Physiol. Zool. 66:437-454.

Beaupre S.J., A.E. Dunham, and K.L. Overall. 1993. Metabolism of a desert lizard: the effects of mass, sex, population of origin, temperature, time of day, and feeding on oxygen consumption of Sceloporus merriami. Physiol. Zool. 66:128147.

Bennett A.F. and W.R. Dawson. 1976. Metabolism. Pp. 127223 in C. Gans and W.R. Dawson, eds. Biology of the Reptilia. Vol. 5. Academic Press, New York.

Bradshaw S.D., H. Saint Girons, and F.J. Bradshaw. 1991. Seasonal changes in material and energy balance associated with reproduction in the green lizard, Lacerta virdis, in western France. Amphibia-Reptilia 12:21-32.

Brown R.P. and V. Perez-Mellado. 1994. Ecological energetics and food acquisition in dense Menorcan islet populations of the lizard Podarcis lilfordi. Funct. Ecol. 8:427-434.

Brown R.P., R.S. Thorpe, and J.R. Speakman. 1992. Comparisons of body size, field energetics, and water flux among populations of the skink Chalcides sexlineatus. Can. J. Zool. 70:1001-1006.

Burnham D.P. and D.R. Anderson. 1992. Data-based selection of an appropriate biological model: the key to modern data analysis. Pp. 16-30 in D.R. McCullough and R.H. Barrett, eds. Wildlife 2001: Populations. Elsevier Applied Science, London.

Christian K.A., L.K. Corbett, B. Green, and B.W. Weavers. 1995. Seasonal activity and energetics of two species of varanid lizards in tropical Australia. Oecologia 103:349-357.

Christian K.A. and B. Green. 1994. Seasonal energetics and water turnover of the frillneck lizard, Chlamydosaurus kingii, in the wet-dry tropics of Australia. Herpetologica 50:274281.

Congdon J.D. 1989. Proximate and evolutionary constraints on energy relations of reptiles. Physiol. Zool. 62:356-373.

Congdon J.D., A.E. Dunham, and D.W. Tinkle 1982. Energy budgets and life histories of reptiles. Pp. 233-271 in C. Gans and F.H. Pough, eds. Biologia of the Reptilia. Vol. 13. Academic Press, New York.

Congdon J.D., W.W. King, and K.A. Nagy. 1978. Validation of the HTO-18 method for determination of $\mathrm{CO}_{2}$ production of lizards (genus Sceloporus). Copeia 1978:360-362.

Edney E.B. 1977. Water Balance in Land Arthropods. Springer, Berlin.

Gessaman J.A. and K.A. Nagy. 1988. Energy metabolism: errors in gas-exchange conversion factors. Physiol. Zool. 61:507513.

Grenot C.J., P. Galina-Tessaro, and S. Alvarez-Cardenas. 1995. Field metabolism of lizards from lower altitude regions of Baja California Sur (Mexico). Amphibia-Reptilia 16:11-23.

Harwood R.H. 1979. The effect of temperature on the digestive efficiency of three species of lizards, Cnemidophorus tigris, Gerrhonotus multicarinatus, and Sceloporus occidentalis. Comp. Biochem. Physiol. 3A:417-433.

Heusner A.A. and E.W. Jameson. 1981. Seasonal changes in oxygen consumption and body composition of Sceloporus occidentalis. Comp. Biochem. Physiol. 69A:363-372.

Jorgensen C.B. 1988. Metabolic costs of growth and maintenance in the toad, Bufo bufo. J. Exp. Biol. 138:319-331.

Karasov W.H. and R.A. Anderson. 1984. Interhabitat differences in energy acquisition and expenditure in a lizard. Ecology 65:235-247.

Mautz W.J. and K.A. Nagy. 1987. Ontogenetic changes in diet, field metabolic rate, and water flux in the herbivorous desert lizard Dipsosaurus dorsalis. Physiol. Zool. 60:640-658.

Merker G.P. and K.A. Nagy. 1984. Energy utilization by freeranging Sceloporus virgatus lizards. Ecology 65:575-581.

Nagy K.A. 1975. Water and energy budgets of free-living animals: measurement using isotopically labeled water. Pp. 227-245 in N.F. Hadley, ed. Environmental Physiology of Desert Organisms. Dowden, Hutchinson, \& Ross, Stroudsburg, Pa.

. 1980. $\mathrm{CO}_{2}$ production in animals: analysis of potential 
errors in the doubly-labeled water method. Am. J. Physiol. 238:R466-R473.

. 1982. Energy requirements of free-living iguanid lizards. Pp. 49-59 in G.M. Burghardt and A.S. Rand, eds. Iguanas of the World: Their Behavior, Ecology, and Conservation. Noyes Publications, Park Ridge, N.J.

- 1983a. Ecological energetics. Pp. 24-54 in R.B. Huey, T. Schoener, and E.R. Pianka, eds. Lizard Ecology. Harvard University Press, Cambridge, Mass.

- 1983b. The Doubly Labeled Water Method: A Guide to Its Use. Publication Number 12(1417). Laboratory of Biomedical and Environmental Sciences, University of California, Los Angeles.

Nagy K.A. and D.P. Costa. 1980. Water flux in animals: analysis of potential errors in the tritiated water method. Am. J. Physiol. 238:R454-R465.

Nagy K.A. and C.C. Peterson. 1988. Scaling of water flux rate in animals. Univ. Calif. Publ. Zool. 120:1-172.

Parry G.D. 1983. The influence of the cost of growth on ectotherm metabolism. J. Theor. Biol. 101:453-477.

Peters R.H. 1983. The Ecological Implications of Body Size. Cambridge University Press, Cambridge.

Pianka E.R. and W.S. Parker. 1972. Ecology of the iguanid lizard Callisarus draconoides. Copeia 1972:493-508.
Schmidt-Nielsen K. 1990. Animal Physiology: Adaptation and Environment. Cambridge University Press, Cambridge.

Tanner W.W. and J.E. Krogh. 1975. Ecology of the zebratailed lizard Callisaurus draconoides at the Nevada Test Site. Herpetologica 31:302-316.

Tsuji J.S. 1988. Seasonal profiles of standard metabolic rate of lizards (Sceloporus occidentalis) in relation to latitude. Physiol. Zool. 61:230-240.

van Marken Lichtenbelt W.D., R. Wesselingh, J.T. Vogel, and K.B.M. Albers. 1993. Energy budgets in free-living green iguanas in a seasonal environment. Ecology 74:1157-1172.

Vernet R., J. Castanet, and M. Baez. 1995. Comparative water flux and daily energy expenditure of lizards of the genus Gallotia (Lacertidae) from the Canary Islands. AmphibiaReptilia 16:55-66.

Vleck D. 1987. Measurement of $\mathrm{O}_{2}$ consumption, $\mathrm{CO}_{2}$ production, and water vapor production in a closed system. J. Appl. Physiol. 62:2103-2106.

Webster M.D. and W.W. Weathers. 1989. Validation of singlesample doubly labeled water method. Am. J. Physiol. 256:R572-R576.

Wilkinson L. 1992. SYSTAT for Windows. SYSTAT, Inc., Evanston, Ill.

Zar J.H. 1974. Biostatistical Analysis. Prentice-Hall, Englewood Cliffs, N.J. 